\title{
ANALISIS HUBUNGAN PENGETAHUAN, PENDAPATAN, POLA MAKAN DENGAN KEJADIAN STUNTING
}

\author{
Yuka Oktafirnanda ${ }^{1 *}$, Hasanah Pratiwi Harahap ${ }^{2}$, Ani Deswita Chaniago ${ }^{3}$ \\ 1,2Program Studi D4 Kebidanan, Fakultas Farmasi dan Kesehatan, Institut Kesehatan Helvetia Medan, \\ Sumatera Utara \\ 3Program Studi D3 Kebidanan, Fakultas Farmasi dan Kesehatan, Institut Kesehatan Helvetia Medan, \\ Sumatera Utara \\ *Korespondensi email : yukaoktafirnanda@helvetia.ac.id
}

\section{ABSTRACT AN ANALYSIS OF CORRELATION OF KNOWLEDGE, INCOME, AND DIET WITH SHORT STATURE}

Background: Short stature is one of many problems nowadays, many factors trigger Short stature in toddlers including mother's knowledge. Most mothers do not know how to process and choose the right food, do not understand a good diet for toddlers, family income is also a factor that led to the limited choice of food, so the food is not varied. Based on preliminary research conducted in Helvetia Village 3 of 5 toddlers undergo short stature. One of them was brief.

Purpose: This study aimed to determine the correlation of knowledge, income, and diet with the incidence of Short stature in Helvetia Village, Labuhan Deli Sub-District.

Methods: The research design used an analytic survey with a cross-sectional approach. It was conducted on June - July 2021. Data were collected by using questionnaires. The populations in this study were all toddlers aged $>2$ - 5 years of 40 toddlers. Data were analyzed by using univariate and bivariate analyses with the ChiSquare test. Meanwhile, the Multivariate used Binary Logistics.

Results: From the results of the chi-square test about mothers' knowledge, family income, and diet significantly associated with the incidence of Short stature in Helvetia Village of Labuhan Deli Sub-District with a $p$-value of $0.00,0.002,0.014$. Based on the Binary logistic variable test, the most dominant influence on the incidence of Short stature was Mothers' Knowledge with $\operatorname{Exp}(B) 5.735$.

Conclusion: Based on the result showed it can be concluded that the correlation of Mother's Knowledge, Family Income, and Diet with Short stature was found in Helvetia Village, Labuhan Deli Sub - District. The most influential variable on Short stature was Mother's Knowledge.

Suggestion Mother's knowledge related to stunting should continue to be improved by holding regular counseling by local health workers. That way mothers can discuss and have broad insight related to nutrition, processing and presentation methods that are right for their children.

Keywords: Knowledge, Income, Diet, Short stature

\section{ABSTRAK}

Latar Belakang: Stunting merupakan salah satu masalah yang banyak terjadi saat ini, banyak faktor pemicu terjadinya stunting pada balita diantaranya pengetahuan ibu, banyak ibu tidak mengetahui cara pengolahan makanan yang tepat dan pemilihan makanan. Kemudian bagaimana pola makan yang baik untuk balita, serta faktor pendapatan keluarga yang menyebabkan terbatasnya pilihan makanan, sehingga makanan anak jadi tidak bervariasi. Survei awal yang dillakukan di Desa Helvetia dari 5 orang balita, 3 diantaranya mengalami stunting dimana 1 orang bertubuh sangat pendek.

Tujuan penelitian ini dilakukan untuk melihat hubungan pengetahuan, pendapatan, dan pola makan dengan kejadian stunting di Desa Helvetia Kecamatan Labuhan Deli.

Metode: Desain Penelitian yang digunkaan adalah survei analitik dengan pendekatan cross sectional. Penelitian dilakukan bulan Juni-Juli 2021. Pengumpulan data menggunakan kuisioner. Populasi dalam penelitian ini yaitu semua balita berusia $>2$ tahun sampai 5 tahun sebanyak 40 orang. Pengambilan sampel menggunakan tekhnik total populasi. Analisa data Univariat, Bivariat dengan Chi-Square dan Multivariat menggunakan Binary Logistik.

Hasil: Dari hasil chi-quare test Pengetahuan Ibu, Pendapatan Keluarga, Pola Makan, secara signifikan berhubungan dengan kejadian stunting di Desa Helvetia Kecamatan Labuhan Deli dengan nilai P-Value 0,00, 
$0,002,0,014$. Dan dari Uji Binary logistic variabel yang paling dominan berpengaruh terhadap kejadian stunting adalah Pengetahuan ibu dengan Exp(B) 5.735.

Kesimpulan: Ada hubungan Pengetahuan Ibu, Pendapatan Keluarga, Pola Makan dengan Kejadian Stunting di Desa Helvetia Kecamatan Labuhan Deli. Variabel paling berpengaruh terhadap stunting adalah Pengetahuan Ibu.

Saran Pengetahuan ibu terkait stunting sebaiknya terus ditingkatkan dengan diadakannya penyuluhanpenyuluhan secara berkala oleh tenaga kesehatan setempat. Dengan begitu ibu-ibu dapat berdiskusi dan punya wawasan yang luas terkait gizi, cara pengolahan dan penyajian yang tepat untuk anaknya.

Kata Kunci : Pengetahuan, Pendapatan, Pola Makan, Stunting

\section{PENDAHULUAN}

Stunting pada anak merupakan dampak defisiensi nutrien selama seribu hari pertama kehidupan, hal ini menimbulkan perkembangan fisik pada anak terhambat. Perkembangan dan peningkatan kualitas hidup anak merupakan upaya penting untuk masa depan Indonesia yang lebih baik. Upaya kelangsungan hidup, perkembangan dan peningkatan kualitas anak berperan penting sejak masa dini kehidupan yaitu masa dalam kandungan, bayi dan anak balita. Pertumbuhan dan perkembangan pada masa balita memerlukan masukan zat-zat gizi yang seimbang dan relatif besar. Hal ini dilakukan untuk mencegah adanya gangguan gizi seperti stunting (Hanifah, 2019).

Stunting merupakan masalah kesehatan masyarakat yang berhubungan dengan meningkatnya risiko kesakitan, kematian dan hambatan pada pertumbuhan baik motorik maupun mental. Stunting dibentuk oleh growth faltering dan catcth up growth yang tidak memadai yang mencerminkan ketidakmampuan untuk mencapai pertumbuhan optimal (Paramashanti, 2019).

Stunting dapat memberikan dampak bagi kelangsungan hidup anak, dampak yang diakibatkan oleh stunting adalah dapat menyebabkan mortalitas dan morbiditas, penurunan perkembangan kognitif, motorik dan bahasa dan berdampak pengeluaran biaya untuk kesehatan, selain itu stunting juga berdampak pada obesitas, penurunan kesehatan reproduksi, penurunan prestasi dan kapasitas belajar dan penurunan kemampuan dan kapasitas kerja di masa depan (Maryunani, 2015). Anak stunting atau bertubuh pendek merupakan indikasi kurangnya asupan gizi, baik secara kuantitas maupun kualitas yang tidak terpenuhi sejak bayi, bahkan sejak dalam kandungan. Selain tubuh pendek stunting dapat menimbulkan dampak lain yaitu gangguan pertumbuhan dan perkembangan. Terdapat beberapa faktor yang mempengaruhi stunting pada anak yaitu pengetahuan, pendidikan, pekerjaan, pendapatan, pola asuh, pola makan, jumlah anggota keluarga, penyakit infeksi, riwayat pemberian ASI Eksklusif, kejadian BBLR dan penyakit kronis (Adriana, 2016).

Gizi pada balita perlu mendapat perhatian yang lebih karena salah satu penyebab kematian balita yang cukup tinggi yaitu keadaan gizi yang buruk. Data dari WHO (World Health Organization) menunjukkan bahwa di Afrika jumlah anak usia 0-59 bulan yang mengalami gizi kurang sebesar $17,8 \%$, sedangkan di Asia tenggara sebesar 19,3\% (Wulandari \& Rahayu, 2019). Prevalensi stunting di Indonesia tahun 2013 sebesar $37,2 \%$ dan tahun 2018 sebesar 30,8\% dengan target RPJM (Rencana Pembangunan Jangka Menengah) tahun 2018 sebesar $28 \%$. Hal ini menunjukkan bahwa penurunan prevalensi kejadian stunting pada balita belum mencapai target RPJM (Rencana Pembangunan Jangka Menengah). Provinsi tertinggi dengan stunting terdapat di Provinsi Papua sebesar 47,3\% (Aridiyah, 2015). Data dari Profil Kesehatan Indonesia tahun 2017, bahwa prevelansi balita usia 0.59 bulan menurut status gizi adalah dengan indeks TB/U di Sumatera Utara Tahun 2016 yakni sangat pendek 9,34\%, pendek $15,10 \%$ sedangkan pada tahun 2017 prevalansi balita usia 0- 59 bulan sangat pendek sebesar $12,50 \%$ dan pendek $16,00 \%$. Hal ini menunjukan bahwa terdapat peningkatan prevalansi balita usia 0-59 bulan di Sumatera Utara yang mengalami stunting (Kementerian Kesehatan RI, 2018). Survei awal yang dilakukan di desa Helvetia pada bulan April, didapatkan dari 5 orang balita, 3 orang diantaranya mengalami srunting, dimana 1 orang dengan kategori sangat pendek.

Upaya pemerintah dalam mengatasi masalah stunting melalui Sustainable Development Goals (SDGs) adalah ibu hamil dan bersalin harus mendapatkan intervensi pada 1000 hari pertama kehidupan, mengupayakan jaminan mutu antenatal care (ANC) terpadu, meningkatkan persalinan di fasilitas kesehatan, menyelenggarakan program pemberian makanan tinggi kalori, protein dan mikronutrien, deteksi dini penyakit, pemberantasan 


\section{JKM (Jurnal Kebidanan Malahayati),Vol 7,No.4.Oktober 2021, \\ ISSN (Print) 2476-8944 ISSN (Online) 2579-762X, Hal 613-619}

cacingan, konseling KB dan Inisiasi menyusu dini. Pada balita meliputi pemantauan pertumbuhan balita, menyelenggarakan kegiatan pemberian makanan tambahan, menyelenggarakan stimulasi dini perkembangan anak dan memberikan pelayanan kesehatan optimal (Yekti, 2020).

\section{METODOLOGI PENELITIAN}

Penelitian ini merupakan penelitian survei analitik dengan pendekatan cross sectional. Penelitian ini dilaksanakan di Desa Helvetia Kecamatan Labuhan Deli, Kabupaten Deli Serdang pada bulan Juni-Juli Tahun 2021. Subjek penelitian ini adalah anak balita usia $>2$ tahun sampai usia 5 tahun. Pengumpulan data menggunakan kuisioner, kemudian pengukuran langsung tinggi badan dan berat badan balita. Sampel diambil dengan teknik total populasi, yaitu semua populasi dijadikan sampel. Adapun jumlah sampel sebanyak 40 orang anak balita di Desa Helvetia. Analisa data dilakukan secara Univariat, Bivariat dengan uji Chi-Square dan Multivariat menggunakan uji Binary Logistik dengan taraf signifikan 0,05 (Sunyoto \& Setiawan, 2013).

\section{HASIL DAN PEMBAHASAN \\ Analisis Deskriptif}

Pada Tabel 1 didapatkan dari analisis deskriptif dengan 40 responden, bahwa responden terbanyak yaitu Balita dengan jenis kelamin laki-laki sebanhyak 24 orang (60\%). Pada variabel pengetahuan, sebagian besar responden berpengetahuan baik sebanyak 29 orang $(72,5 \%)$. Variabel pendapatan keluarga rata-rata pendapatan perbulannya memenuhi UMR setempat yaitu $R p$ $2.500 .000,00$. Untuk variabel pola makan, sebagian besar pola makan balita teratu yaitu sebanyak 30 orang $(75 \%)$, hanya sebagian kecil yang tidak teratur pola makannya

Tabel 1.

Distribusi Frekuensi Responden Berdasarkan Jenis Kelamin, Pengetahuan Ibu, Pendapatan, Pola Makan, Cemilan Anak, dan Riwayat ASI di Desa Helvetia Tahun 2021

\begin{tabular}{lcc}
\hline \multicolumn{1}{c}{ Jenis Kelamin Balita } & N & $\%$ \\
\hline $\begin{array}{l}\text { Perempuan } \\
\text { Laki-laki }\end{array}$ & 16 & 40.0 \\
$\begin{array}{l}\text { Pengetahuan Ibu } \\
\text { Kurang Baik }\end{array}$ & 24 & 60.0 \\
$\quad$ Baik & 11 & 27.5 \\
$\begin{array}{l}\text { Pendapatan Keluarga } \\
\quad<2.500 .000\end{array}$ & 29 & 72.5 \\
$\quad$ >= 2.500.000 & 13 & 32.5 \\
$\begin{array}{l}\text { Pola Makan } \\
\text { Tidak Teratur }\end{array}$ & 27 & 67.5 \\
$\quad$ Teratur & 10 & 25.0 \\
\hline \multicolumn{1}{c}{ Total } & 30 & 75.0 \\
\hline
\end{tabular}

Tabel 2.

Distribusi Frekuensi Kejadian Stunting di Desa Helvetia Tahun 2021

\begin{tabular}{ccc}
\hline Kategori & N & $\%$ \\
\hline Stunting & 11 & 27.5 \\
Tidak Stunting & 29 & 72.5 \\
\hline Total & 40 & 100.0 \\
\hline
\end{tabular}

Pada tabel 2 dapat dilihat bahwa, dari 40 responden sebagian besar balita tidak mengalami stunting yaitu sebanyak 29 orang $(72,5 \%)$, namun ada 11 orang balita yang mengalami stunting dengan persentase $27,5 \%$.

\section{Analisis Bivariat}

Dari tabel 3 terlihat bahwa pengetahuan ibu berhubungan sangat signifikan dengan kejadian stunting, dengan nilai P-Value sebesar 0,00 . Sebagian besar ibu dengan pengetahuan baik dan balita tidak stunting yaitu sebanyak 27 orang.

Tabel 3.

Distribusi Hubungan Pengetahuan dengan Kejadian Stunting di Desa Helvetia Tahun 2021

\begin{tabular}{lcccccc}
\hline \multirow{2}{*}{ Kejadian Stunting } & \multicolumn{2}{c}{ Pengetahuan Ibu } & \multirow{2}{*}{ N } & $\%$ & \multirow{2}{*}{ P-Value } \\
\cline { 2 - 3 } & Kurang Baik & Baik & & & \\
\hline Stunting & 9 & 2 & 11 & 27,5 & \multirow{2}{*}{0,000} \\
Tidak Stunting & 2 & 27 & 29 & 72,5 & \\
\hline \multicolumn{1}{c}{ Total } & 11 & 29 & 40 & 100 & \\
\hline
\end{tabular}

Dari Tabel 4 dapat dilihat bahwa pendapatan keluarga berhubungan secara signifikan dengan kejadian stunting dengan $\mathrm{p}$-Value sebesar 0,002. Sebagian besar responden memiliki pendapatan keluarga $\geq U M R$ yaitu $\mathrm{Rp} 2.500 .000$ dan balita tidak stunting sebanyak 24 orang, hanya sebagian kecil responden dengan penghasilan $\geq$ UMR dan balita mengalami stunting. 
Tabel 4.

Distribusi Hubungan Pendapatan Keluarga dengan Kejadian Stunting di Desa Helvetia Tahun 2021

\begin{tabular}{|c|c|c|c|c|c|}
\hline \multirow{2}{*}{ Kategori Stunting } & \multicolumn{2}{|c|}{ Pendapatan } & \multirow{2}{*}{$\mathbf{N}$} & \multirow{2}{*}{$\%$} & \multirow{2}{*}{ P-Value } \\
\hline & $<2,5 \mathrm{jt}$ & $\geq 2,5 j t$ & & & \\
\hline Stunting & 8 & 3 & 11 & 27,5 & \\
\hline Tidak Stunting & 5 & 24 & 29 & 72,5 & 0,002 \\
\hline Total & 13 & 27 & 40 & 100 & \\
\hline
\end{tabular}

Dari tabel 5 bisa kita lihat bahwa pola makan berhubungan secara signifikan dengan kejadian stunting, dengan nilai $p$-Value sebesar 0,014. Sebagian besar balita memiliki pola makan teratur dan tidak mengalami stunting sebanyak 25 orang, sedangkan pola makan teratur yang mengalami stunting hanya 5 orang balita.

Tabel 5.

Distribusi Hubungan Pola Makan dengan Kejadian Stunting di Desa Helvetia Tahun 2021

\begin{tabular}{lccccc}
\hline \multirow{2}{*}{ Kategori Stunting } & \multicolumn{2}{c}{ Pola Makan } & \multirow{2}{*}{ N } & \multirow{2}{*}{$\%$} & \multirow{2}{*}{ P-Value } \\
\cline { 2 - 3 } & Tidak Teratur & Teratur & & & \\
\hline Stunting & 6 & 5 & 11 & 27,5 & \multirow{2}{*}{0,014} \\
Tidak Stunting & 4 & 25 & 29 & 72,5 & \\
\hline \multicolumn{1}{c}{ Total } & 10 & 30 & 40 & 100 & \\
\hline \multicolumn{1}{c}{} & & & &
\end{tabular}

\section{Multivariat}

Dari Tabel 6 dibawah ini, dapat dilihat bahwa dari 3 variabel yang tidak tereliminasi ada 1 variabel yaitu Pengetahuan Ibu. Maka variabel yang paling berpengaruh terhadap kejadian stunting adalah pengetahuan ibu dengan nilai $\operatorname{Exp}(\mathrm{B})$ paling besar yaitu 5.735 .

Tabel 6.

Pengaruh Pengetahuan Ibu, Pendapatan Keluarga, Pola Makan, dan Cemilan Anak Terhadap Kejadian Stunting di Desa Helvetia Tahun 2021

\begin{tabular}{llrrrrrrrc}
\hline & & \multicolumn{1}{c}{ B } & \multicolumn{1}{c}{ S.E. } & Wald & df & Sig. & \multirow{2}{*}{ Exp(B) } & \multicolumn{2}{c}{ 95\% C.Ifor EXP(B) } \\
\cline { 7 - 10 } & & & \multicolumn{1}{c}{ Lower } & Upper \\
\hline Step 1a & Kat_Pengetahuan & 19.312 & 6113.199 & .000 & 1 & .997 & 4.518 & .000 &. \\
& Pendapatan & 1.393 & 1.437 & .939 & 1 & .332 & .987 & .241 & 67.292 \\
& Pola_Makan & -16.895 & 6113.199 & .000 & 1 & .998 & .827 & .000 &. \\
\hline \multirow{2}{*}{ Step 2a } & Constant & -41.594 & 9038.369 & .000 & 1 & .996 & .000 & & \\
& Kat_Pengetahuan & 2.858 & 1.425 & 4.021 & 1 & .045 & 5.106 & 1.067 & 284.567 \\
& Pendapatan & 1.322 & 1.412 & .878 & 1 & .349 & .920 & .236 & 59.668 \\
& Constant & -27.331 & 7876.147 & .000 & 1 & .997 & .000 & & \\
\hline Step 3a & Kat_Pengetahuan & 2.890 & 1.364 & 4.489 & 1 & .034 & 5.735 & 1.242 & 260.918 \\
& Constant & -26.061 & 7916.674 & .000 & 1 & .997 & .000 & & \\
\hline
\end{tabular}

\section{PEMBAHASAN}

Hubungan Pengetahuan Ibu dengan Kejadian Stunting

Pengetahuan merupakan hasil dari "tahu", dan ini terjadi setelah orang melakukan penginderaan terhadap suatu objek tertentu. Penginderaan terjadi melalui panca indera manusia, yakni indera penglihatan, pendengaran, penciuman, rasa dan raba. Sebagian besar pengetahuan diperoleh melalui mata dan telinga. Pengetahuan atau kognitif merupakan domain yang sangat penting dalam membentuk tindakan seseorang (Notoatmodjo, 2012) .Pengetahuan mengenai gizi merupakan proses awal dalam perubahan perilaku peningkatan status gizi, sehingga pengetahuan merupakan faktor internal yang mempengaruhi perubahan perilaku. Pengetahuan ibu tentang gizi akan menentukan sikap dan perilaku ibu dalam menyediakan makanan dengan jenis dan jumlah yang tepat agar anak dapat tumbuh dan berkembang secara optimal (Yuliana et al., 2019) 


\section{JKM (Jurnal Kebidanan Malahayati),Vol 7,No.4.Oktober 2021, \\ ISSN (Print) 2476-8944 ISSN (Online) 2579-762X, Hal 613-619}

Pengetahuan ibu sangat lah berperan penting dengan kejadian stunting, karena kurangnya pengetahuan ibu tentang makanan yang mengandung zat gizi dan cara memperlakukan bahan pangan dalam pengolahan yang benar seperti cara membersihkan kotoran yang ada pada bahan pangan, kemudian secara berlebihan dalam memasaknya, terlalu matang sehingga merusak dan mengurangi zat gizi yang dikandungnya. Selain itu gizi kurang juga dapat disebabkan karena kurangnya pengetahuan ibu tentang upaya mengatur menu makanan yang seimbang (Olsa et al., 2018).

Pengaturan menu, pengolahannya serta penyediaan makanan untuk keluarga khususnya bagi balita yang masih dalam proses pertumbuhan, harus diperhatikan aspek gizinya sehingga kebutuhan akan zat-zat gizi yang penting bagi tubuh dapat terpenuhi seperti karbohidrat, protein, vitamin A dan zat besi. Untuk menyusun menu yang adekuat, seseorang perlu memiliki pengetahuan yang adekuat pula mengenai bahan makanan dan zat gizi, kebutuhan gizi seseorang serta pengetahuan hidangan dan pengolahannya (Wellina et al., 2016).

\section{Hubungan Pendapatan Keluarga dengan Kejadian Stunting}

Salah satu faktor penyebab kurang gizi pada balita adalah status sosial ekonomi, dimana tingkat penghasilan keluarga sangat menentukan jenis pangan yang akan dibeli dengan adanya tambahan penghasilan. Seseorang dengan status sosial ekonomi rendah membelanjakan sebagian besar untuk kebutuhan hidup, sedangkan seseorang dengan status sosial ekonomi tinggi membelanjakan sebagian besar untuk penunjang kebutuhan hidup seperti vitamin, susu, dan lain-lai. Jadi penghasilan merupakan faktor penting bagi kuantitas dan kualitas makanan. Antara penghasilan dan gizi jelas ada hubungan yang menguntungkan (Nurmayasanti \& Mahmudiono, 2019).

Keluarga dengan pendapatan terbatas mempunyai kemungkinan kurang dapat memenuhi kebutuhan makanan sejumlah yang diperlukan, setidaknya keanekaragaman bahan makanan kurang dapat dijamin karena dengan uang terbatas itu tidak akan banyak pilihan untuk menyediakan bahan makanan. Masyarakat yang berpenghasilan rendah biasanya membelanjakan sebagian besar dari pendapatan untuk membeli makanan. Pendapatan juga menentukan jenis pangan yang akan dikonsumsi (Hidayat \& Ismawati, 2019).
Penelitian Dewi, tentang Faktor-faktor yang berhubungan dengan kejadian stunting pada balita 24-36 bulan di wilayah kerja UPTD Puskesmas Gadingrejo dengan salah satu variabel status ekonomi nilai P-Value 0,004. Dimana keluarga dengan penghasilan dibawah UMP cenderung memiliki balita stunting di bandingkan dengan keluarga yang berpendapatan diatas UMP. Hal ini disebabkan karena keluarga dengan pendapatan diatas UMP akan mampu memenuhi kebutuhan primer dan sekunder anak dan asupan nutrisi anak terpenuhi sesuai kebutuhan sehingga anak dapat tumbuh secara optimal, sedangkan keluarga dengan pandapatan dibawah UMP cenderung mengkonsumsi makanan dalam segi kuantitas dan kurang kualitas dan kurang bervariasi sehingga mempengaruhi asupan nutrisi anak yang kurang dari kebutuhan (Dewi et al., 2019).

\section{Hubungan Pola Makan Balita dengan Kejadian Stunting}

Pola pemberian makan merupakan perilaku yang dapat mempengaruhi status gizi. Pola pemberian makan adalah gambaran asupan gizi mencakup macam, jumlah, dan jadwal makan dalam pemenuhan nutrisi (Kemenkes RI, 2014).

Pengaturan pola makan balita hal yang sangat penting untuk diperhatikan seorang ibu, pola makan yang teratur dengan jenis makanan yang bervariasi akan menentukan status gizi anak. Balita berada pada usia emas, sehingga jika ibu tidak mengontrol pola makan anak dengan baik maka akan berefek sangat buruk bagia anak dimasa depan.

Jenis konsumsi makanan sangat menentukan status gizi seorang anak, makanan yang berkualitas baik jika menu harian memberikan komposisi menu yang bergizi, berimbang dan bervariasi sesuai dengan kebutuhannya (Hayati et al., 2012). Dengan begitu pola makan memang penting diperhatikan oleh seorang ibu dalam memenuhi asupan nutrisi anak, namun komposisi dan zat gizi yang terkandung di dalam makanan tersebut juga hal yang tidak kalah penting untuk diprioritaskan. Menu dengan gizi yang seimbang, makanan yang bervariasi dan pola makan yang teratur adalah salah satu cara mencegah stunting pada anak.

\section{Pengaruh Pengetahuan lbu, Pendapatan Keluarga, dan Pola Makan Terhadap Kejadian Stunting}

Dari analisis data menggunakan binary logistic test yang telah dilakukan, dari 3 variabel yaitu Pengetahuan Ibu, Pendapatan Keluarga, dan 
Pola Makan Anak yang paling berpengaruh terhadap kejadian stunting adalah Pengetahuan lbu karena memiliki nilai $\operatorname{Exp}(B)$ paling tinggi. Pengetahuan ibu disini mencakup tentang gizi, cara pengolahan dan penyajian makanan yang benar serta pengetahuan ibu mengenai stunting pada anak balita.

Pengetahuan ibu memang pondasi utama agar anak bisa tumbung dan berkembang dengan baik. Khususnya masalah penyediaan dan pengolahan makan untuk keluarga. Pengetahuan merupakan faktor tidak langsung yang berpengaruh terhadap status gizi balita dan memiliki peran penting. Gangguan gizi pada balita terjadi karena pengetahuan yang kurang mengenai kebutuhan makanan. Pengetahuan mengenai gizi merupakan proses awal dalam perubahan perilaku peningkatan status gizi, sehingga pengetahuan merupakan faktor internal yang mempengaruhi perubahan perilaku. Pengetahuan ibu tentang gizi akan menentukan sikap dan perilaku ibu dalam menyediakan makanan dengan jenis dan jumlah yang tepat agar anak dapat tumbuh dan berkembang secara optimal, sehingga tidak terjadi stunting pada anak (Olsa et al., 2018).

Prevalensi stunting meningkat dengan bertambahnya usia, peningkatan terjadi dalam 2 tahun pertama kehidupan, proses pertumbuhan anak masa lalu mencerminkan standar gizi dan kesehatan (Komalasari et al., 2021).

Selain pengetahuan ibu, pendapatan keluarga dan pola makan juga menjadi salah satu faktor penyebab stunting pada anak, meskipun tereliminasi pada analisis multivariate, tetap ia berhubungan secara signifikan dengan kejadian stunting. Dari penelitian yang telah dilakukan, ada 8 orang balita yang mengalami stunting pada keluarga dengan pendapatan dibawah UMR.

Daya beli keluarga untuk makanan bergizi dipengaruhi oleh pendapatan keluarga karena dalam menentukan jenis pangan yang akan dibeli tergantung pada tinggi rendahnya pendapatan. Daya beli pangan rumah tangga mengikuti tingkat pendapatan keluarga, dengan pendapatan yang tinggi dapat dimungkinkan terpenuhinya kebutuhan makanan seluruh anggota keluarga, namun sebaliknya tingkat pendapatan yang rendah mengakibatkan rendahnya daya beli pangan rumah tangga. Daya beli terhadap bahan pangan yang rendah menyebabkan kurang terpenuhinya kebutuhan zat gizi balita (Paramashanti, 2019)

Untuk variabel pola makan terdapat 5 orang balita mengalami stunting dengan pola makan yang tidak teratur. Keteraturan pola makan pada anak balita adalah salah satu faktor tidak langsung penyebab stunting, dimana saat ibu sudah memberikan makan secara teratur kepada anak ada hal lain yang perlu mendapat perhatian, yaitu jenis konsumsi makanan yang diberikan setiap harinya kepada anak. Semakin banyak jenis dan variasi makanan yang diberikan pada anak, baik protein hewani, nabati, buah, sayur, dan sebagainya maka semakin kecil kemungkinan terjadi stunting pada anak (Hayati et al., 2012).

\section{SIMPULAN}

Pengetahuan Ibu, Pendapatan Keluarga, dan Pola makan anak berhubungan secara signifikan dengan kejadian stunting di Desa Helvetia Kecamatan Labuhan Deli Tahun 2021. Dimana variabel yang paling memengaruhi kejadian stunting adalah Pengetahuan Ibu.

\section{SARAN}

terus ditingkatkan dengan diadakannya penyuluhan-penyuluhan secara berkala oleh tenaga kesehatan setempat. Dengan begitu ibu-ibu dapat berdiskusi dan punya wawasan yang luas terkait gizi, cara pengolahan dan penyajian yang tepat untuk anaknya. Diharapkan untuk penelitian selanjutnya melakukan pengkajian tentang variasi makanan, cemilan anak, sanitasi dan pola asuh anak.

\section{DAFTAR PUSTAKA}

Adriana. (2016). Pengantar Gizi Masyarakat. Kencana Prenada Media Group.

Aridiyah, F. O. (2015). Faktor-Faktor Yang Mempengaruhi Kejadian Stunting Pada Anak Balita di Wilayah Pedesaan dan Perkotaan di Kabupaten Jember. 9/61793. http://repository.unej.ac.id

Dewi, A. P., Ariski, T. N., \& Kumalasari, D. (2019). Faktor-Faktor yang Berhubungan dengan Kejadian Stunting pada Balita 24-36 Bulan di Wilayah Kerja UPT Puskesmas Gadingrejo Kabupaten Pringsewu. Wellness And Healthy Magazine, 1(2), 231-237.

Hanifah. (2019). Gizi Dalam Siklus Daur Kehidupan. CV Andi Utama.

Hayati, A. W., Hardinsyah, H., Jalal, F., Madanijah, S., \& Briawan, D. (2012). Pola Konsumsi Pangan dan Asupan Energi dan Zat Gizi Anak Stunting dan Tidak Stunting 0-23 Bulan. Jurnal Gizi Dan Pangan, 7(2), 73-80.

Hidayat, A. N., \& Ismawati, I. (2019). Faktor-Faktor Kejadian Stunting Pada Balita di Wilayah Kerja UPT Puskesmas Kramatwatu Kabupaten Serang. Jurnal BIMTAS: Jurnal 
Kebidanan Umtas, 3(1), 28-35.

Kemenkes RI. (2014). Profil Kesehatan Indonesia. www.kemenkes.go.id

Kementerian Kesehatan RI. (2018). Profil Kesehatan Indonesia 2017. 1227.

Komalasari, K., Supriati, E., Sanjaya, R., \& Ifayanti, H. (2021). Faktor-Faktor Penyebab Kejadian Stunting Pada Balita. Majalah Kesehatan Indonesia, 2(1), 51-56.

Maryunani, A. (2015). IImu Kesehatan Anak Dalam Kebidanan. Trans Info Media.

Notoatmodjo, S. (2012). Promosi Kesehatan Dan Perilaku Kesehatan. Rineka Cipta.

Nurmayasanti, A., \& Mahmudiono, T. (2019). Status Sosial Ekonomi dan Keragaman Pangan Pada Balita Stunting dan Non-Stunting Usia 24-59 Bulan di Wilayah Kerja Puskesmas Wilangan Kabupaten Nganjuk. Amerta Nutrition, 3(2), 114-121.

Olsa, E. D., Sulastri, D., \& Anas, E. (2018). Hubungan sikap dan pengetahuan ibu terhadap kejadian stunting pada anak baru masuk Sekolah Dasar di kecamanatan Nanggalo. Jurnal Kesehatan Andalas, 6(3), 523-529.

Paramashanti, A. (2019). Gizi Bagi Ibu dan Anak. CV. Pustaka Baru.

Sunyoto, D., \& Setiawan, A. (2013). Buku Ajar: Statistik Kesehatan.

Wellina, W. F., Kartasurya, M. I., \& Rahfiludin, M. Z. (2016). Faktor Risiko Stanting Pada Anak Umur 12-24 Bulan.

Wulandari, W., \& Rahayu, F. (2019). Analisis Faktor Resiko Kejadian Stunting di Pukesmas Kerkap Bengkulu Utara. 1st Prosiding Seminar Nasional Fakultas IImu Kesehatan, $50-54$

Yekti, R. (2020). SDGs (Sustainable Development Goals) Dan 1000 Hari Pertama Kehidupan.

Yuliana, W., ST, S., Keb, M., \& Hakim, B. N. (2019). Darurat stunting dengan melibatkan keluarga. Yayasan Ahmar Cendekia Indonesia. 